\title{
Homeobox gene Rhox5 is regulated by epigenetic mechanisms in cancer and stem cells and promotes cancer growth
}

\author{
Qiang Li ${ }^{1,2}$, Mark E O'Malley ${ }^{1,2}$, David L Bartlett ${ }^{1,2}$ and Z Sheng Guo ${ }^{1,2^{*}}$
}

\begin{abstract}
Background: Homeobox genes murine Rhox5 and human RHOXF1 are expressed in early embryonic stages and then mostly restricted to germline tissues in normal adult, yet they are aberrantly expressed in cancer cells in vitro and in vivo. Here we study the epigenetic regulation and potential functions of Rhox5 gene.

Findings: In Rhox 5 -silenced or extremely low expresser cells, we observed low levels of active histone epigenetic marks ( $\mathrm{H3ac}, \mathrm{H} 4 \mathrm{ac}$ and $\mathrm{H} 3 \mathrm{~K} 4 \mathrm{me} 2$ ) and high levels of repressive mark $\mathrm{H} 3 \mathrm{~K} 9 \mathrm{me} 2$ along with DNA hypermethylation in the promoter. In Rhox5 low expresser cells, we typically observed modest levels of both active and repressive histone marks along with moderate DNA methylation. In Rhox 5 highly expressed CT26 cancer cells, we observed DNA hypomethylation along with high levels of both active and repressive histone marks. Epigenetic drugs (retinoic acid and MS-275) induced F9 cell differentiation with enhanced Rhox5 expression and dynamic changes of epigenetic marks. Finally, Rhox5 knockdown by small hairpin RNA (shRNA) in CT26 colon cancer decreased cell proliferation and migration in vitro and tumor growth in vivo .

Conclusions: Both DNA methylation and histone methylation/acetylation play key roles in modulating Rhox5 expression in various cell types. The stem cell-like "bivalent domain", an epigenetic feature originally identified in key differentiation genes within stem cells, exists in the Rhox5 gene promoter in not only embryonic stem cells but also cancer cells, cancer stem cells, and differentiated Sertoli cells. As Ras signaling-dependent Rhox5 expression promotes tumor growth, Rhox5 may be an ideal target for therapeutic intervention in cancer.
\end{abstract}

\section{Background}

The reproductive homeobox on X-chromosome (Rhox) gene cluster in mouse contains 33 known genes [1], and three members of this gene family (Rhox2, Rhox $4 b$ and Rhox 5 ) are crucial for self-renewal and differentiation of embryonic stem (ES) cells [2-4]. The founding member of Rhox gene cluster, Rhox5 (formerly pem), is expressed in early embryos and ES cells [5-7], embryonic carcinoma (EC) cells, and primordial and pre-muscle stem cells [8]. Intriguingly, Rhox5 is predominantly expressed in female blastocysts from the paternally inherited X chromosome [7], yet the paternal copy is silent in placenta cells [9]. In adult mice, Rhox5 expression is restricted to germline tissues in both male and

\footnotetext{
* Correspondence: guozs@upmc.edu

${ }^{1}$ The University of Pittsburgh Cancer Institute, University of Pittsburgh,

Pennsylvania 15213, USA

Full list of author information is available at the end of the article
}

female and is silenced in most somatic tissues $[1,10,11]$. Rhox 5 is expressed from its two promoters, a distal promoter $(\mathrm{Pd})$ and a proximal promoter $(\mathrm{Pp})$, that give rise to transcripts with different 5 '-ends encoding the same protein. The transcription from Pp depends on both androgen receptor and androgen [10]. Rhox5 plays an essential role in self-renewal and differentiation of ES cells. It has been shown that Rhox 5 over-expression is able to maintain murine ES cells in a pluripotent state in a leukemia inhibitory factor-independent manner [6], and can also block ES cell differentiation [3,11]. It promotes differentiation and survival of germ cells in germline tissues [10]. Targeted disruption of Rhox5 increases male germ cell apoptosis and reduces sperm production, sperm motility, and fertility [12].

Rhox 5 is expressed not only in established cancer cell lines [13-15], but also in cancers in vivo, e.g., adenomas and carcinomas in the $\mathrm{APC}^{\mathrm{Min} /+}$ mice and large

\section{Biomed Central}


intestine tumors of Msh2-deficient mice conditionally expressing K-ras (V12) [16,17]. The Pd promoter was regarded as the promoter directing the aberrant expression in tumor cells [10].

Rhox5 may exert important functions in cancer based on the following evidence. First, partners for Rhox 5 include: menin, a tumor suppressor [18], prosaposin, a multifunctional protein [19], and the cell division cycle 37 (Cdc37) homolog protein [20]. Second, Rhox5 also mediates transcriptional repression of the netrin-1 receptor gene $U n c 5 c$, a tumor suppressor in colorectal cancer [21]. Third, Rhox 5 gene Pd activity in tumor cells requires Ras signaling [22]. Fourth, in a colon adenoma model induced by conditional activation of K-ras ${ }^{\mathrm{V} 12}$ in Msh2 knockout mice, Rhox5 is one of three genes significantly up-regulated [17]. Finally, Rhox 5 renders tumor cells resistant to apoptotic cell death induced by anticancer therapies [23]. In addition, it may play a role in cancer initiating cells (or cancer stem [CS] cells) [24]. CS cells are cancer cells that possess characteristics associated with normal stem cells. They have the ability to give rise to all cell types found in a particular tumor. It is possible that ES and CS cells share some key regulatory genes that are tightly regulated by similar epigenetic mechanisms.

While there are a total of 33 known Rhox genes clustered in the $\mathrm{X}$ chromosome in mouse [1], only two RHOX genes have been characterized in humans: RHOXF1 (originally called OTEX and hPEPP1) and RHOXF2A (originally hPEPP2) [25,26]. While there is no human homolog of mouse Rhox5, human RHOXF1 is closest to murine Rhox 5 in terms of chromosomal location of the gene, tissue expression profiles, and potential functions. RHOXF1 is expressed at relatively high levels in human ES cells and adult germline stem cells [27]. It is expressed in human colorectal cancer and testicular seminoma in vivo $[28,29]$, as well as in some cancer cell lines $[15,26]$. Therefore, it is possible that Rhox5 and RhoxF1 may have comparable functions despite low sequence conservation and therefore they may be considered orthologues.

DNA methylation regulates gene expression in normal mammalian development $[30,31]$. In cancer, aberrant promoter hypermethylation plays a major role in transcriptional silencing of critical growth regulators such as tumor suppressor genes [32,33], while aberrant promoter hypomethylation upregulates germline genes (such as Rhox5 ) that are normally expressed in embryo stages and stem cells yet silenced in all or most somatic tissues $[34,35]$. Histone modifications together with DNA methylation in the chromatin regulate many regulatory genes [36,37]. All known acetylations of histones are correlated with transcriptional activation [38]. Histone methylations at lysine and arginine residues are another class of epigenetic marks $[39,40]$. A recent highresolution profiling study in the human genome indicated that $\mathrm{H} 3 \mathrm{~K} 4$ trimethylation and the monomethylations of H3K9, H3K27, H3K79, H4K20 and H2BK5 are linked to gene activation, whereas trimethylations of H3K27, H3K9 and H3K79 are linked to repression [40]. In addition, a "bivalent domain" (repressive mark H3K27me3 and permissive mark H3K4me2/me3) marks key developmental genes in ES cells $[41,42]$. This chromatin bivalent domain in stem/progenitor cells predisposes tumor suppressor genes to DNA hypermethylation and heritable silencing [43-45].

RHOX 5 may be regulated by epigenetic mechanisms. First, DNA methylation regulates long-range silencing of Rhox gene cluster including Rhox 5 during the postimplantation development of mice [46]. Second, Rhox5 could be upregulated in ES cells and embryonic fibroblast cells by inactivation of DNA methyltransferase genes [46,47], or in ES cells null for linker histone H1 [48]. While this paper was under revision, Wilkinson, MacLean, and coworkers showed that the Rhox gene cluster is imprinted and regulated by histone $\mathrm{H} 1$ and DNA methylation in ES cells [9]. Third, Rhox5 is one of the X-linked cancer-germline (CG) genes, many of which are regulated by DNA methylation $[14,35,49]$. Finally, we have demonstrated that epigenetic drugs could upregulate Rhox5 in cancer cells through enrichment of active histone marks in the promoter region preferentially with DNA demethylation [15].

We and our collaborators have previously investigated epigenetic regulation of genes in normal development and cancer [15,35,50-52]. In this study, we have confirmed that Rhox 5 is expressed in ES cells, EC cells, and cancer cells. We found that Rhox5 is expressed in side population (SP) cells that enrich for cancer stem/progenitor cells. We have examined the epigenetic marks in the promoter region, including both DNA methylation and histone acetylation (H3ac, H4ac and H3K9ac) and methylation (H3K4me2, H3K9me2 and H3K27me3), and related them to levels of expression in various cells types. We showed that epigenetic drugs could induce differentiation of F9 teratocarcinoma cells, but not SP cells, with Rhox5 upregulation and concurrent epigenetic changes. Finally, we demonstrated that Rhox5 gene knockdown by small hairpin RNA (shRNA) in CT26 colon cancer cells resulted in reduced tumor cell migration and cell proliferation in vitro and attenuated tumor growth in vivo .

\section{Results}

\section{Expression of Rhox 5 gene in ES cells, somatic cells and} cancer cells

Rhox 5 gene transcription is controlled by dual promoters, Pd and Pp, producing mRNAs with different 5' 


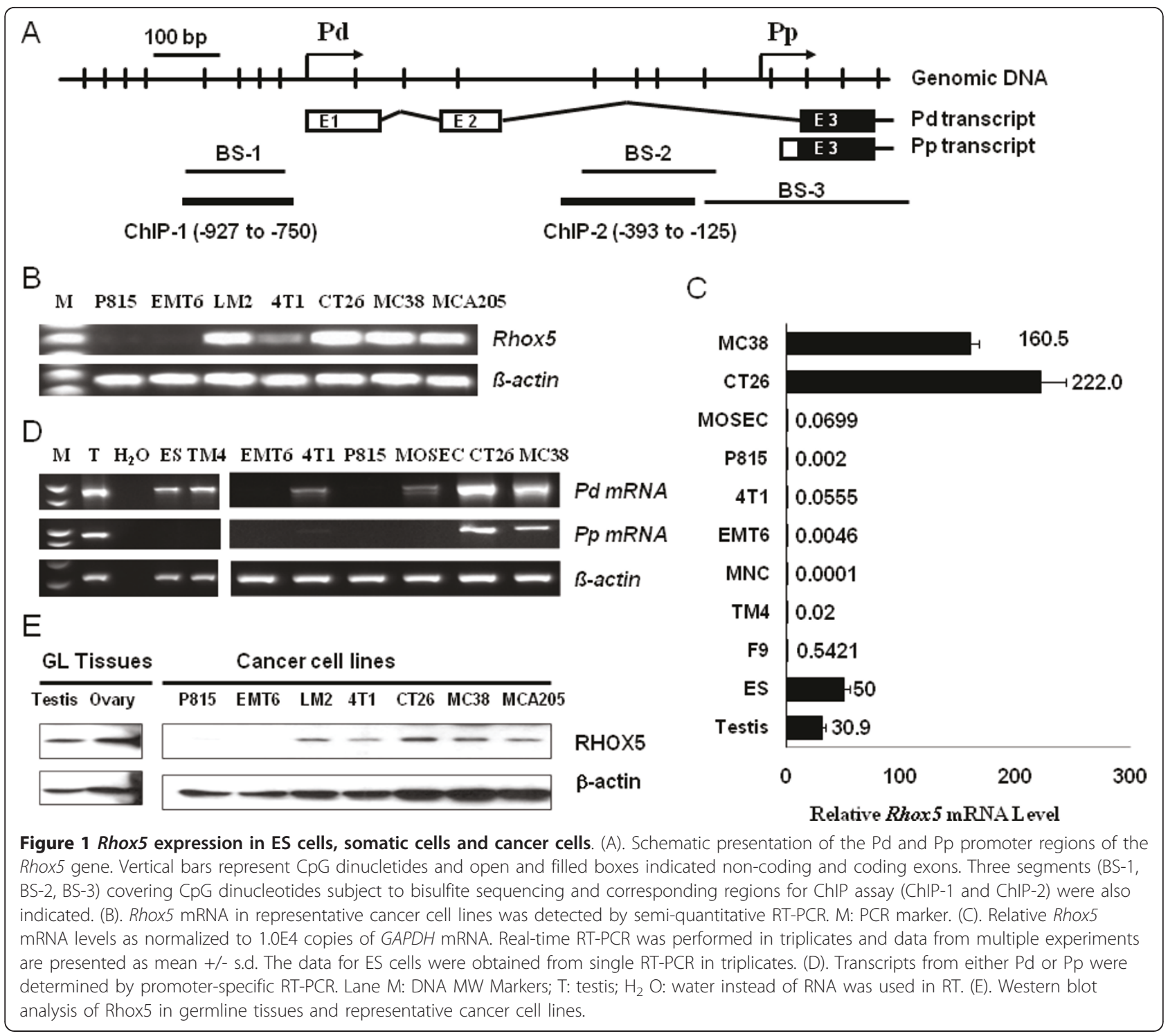

ends yet encoding the same protein (Figure 1A). We initially examined Rhox 5 expression in cancer cells as well as in ES cells and germline tissues. As shown in Table 1, Rhox 5 mRNA was detected in all 26 cancer cell lines tested. These cancer lines were derived from 12 different tissues. Two cancer cell lines (EMT6 and P815) generated faint bands after 35 cycles of PCR following reverse transcription (RT) (Figure 1B). In contrast, another cancer-germline gene, $\mathrm{P} 1 \mathrm{~A}$, which we studied previously, was expressed in a much smaller fraction of cancer cell lines. We then quantified Rhox 5 mRNA from representative tissues or cells by RT-qPCR (Figure 1C). Testis tissue expressing Rhox 5 mRNA was utilized as a positive control. ES and F9 EC cells expressed low levels of Rhox 5 mRNA. Normal somatic cells such as mononucleocytes (MNC) did not express
Rhox 5 mRNA. Rhox 5 expression in cancer cells varied over a wide range, with high levels in CT26 and MC38 cells and extremely low levels in EMT6 and P815 cells.

We next analyzed promoter-specific transcription from both Pd and Pp of Rhox5 gene in selected normal cells and cancer cells by promoter-specific RT-PCR as described previously [15]. As shown in Figure 1D, testis tissue utilized both Pd and Pp for transcription, while ES cells utilized the Pd promoter for transcription. TM4 Sertoli cells utilized mainly Pd, consistent with results from a previous study [53]. Among the selected group of cancer cells, CT26, MC38, and 4T1 cells utilized both $\mathrm{Pd}$ and Pp for transcription. Rhox 5 mRNA was barely detectable in EMT6 and P815 cells.

We further confirmed gene expression at the protein level by Western blot analysis (Figure 1E). Both 
Table 1 Rhox5 and P1A mRNA expression in mouse cancer cells

\begin{tabular}{llllllll}
\hline $\begin{array}{l}\text { Tumor } \\
\text { type }\end{array}$ & $\begin{array}{l}\text { Cell } \\
\text { line }\end{array}$ & Rhox5 & P1A & Tumor type & $\begin{array}{l}\text { Cell } \\
\text { line }\end{array}$ & Rhox5 & P1 \\
\hline Mammary & 4T1 & + & - & Lung & LLC & + & - \\
\hline & C3-L5 & + & - & & LM2 & + & - \\
\hline C127l & + & - & & M109 & + & - \\
\hline & EMT6 & $+/-$ & - & Fibrosarcoma & MCA102 & + & - \\
\hline & MM2MT & + & - & & MCA205 & + & - \\
\hline TS/A & + & - & Hepatoma & Hepa1-6 & + & $-/+$ \\
\hline TUBO & + & - & Lymphoma & A20 & + & + \\
\hline Colorectal & CA07/A & + & - & & EL4 & + & + \\
\hline & CA51 & + & + & Mastocytoma & P815 & $-/+$ & + \\
\hline & CMT93 & + & - & Melanoma & B16 & + & - \\
\hline CT26 & + & - & Ovarian & MOSEC & + & - \\
\hline MC38 & + & - & Pancreatic & Panc02 & + & - \\
\hline Leukemia & L1210 & + & - & EC & F9 & + & +
\end{tabular}

* Footnote: "+" represents a strong while "-/+" very weak and "-" undetectable signals of CDNA amplification after 35 cycles of PCR following reverse

transcription (RT). The status of P1A expression in some cancer cell lines has been reported in our previous study [35].

germline tissues (testis and ovary) and selected cancer cells expressed Rhox 5 protein $(\sim 30 \mathrm{kDa})$. In contrast, Rhox 5 protein was below the level of detection in EMT6 and P815 cancer cells. These results were consistent with those obtained by RT-PCR.

\section{RHOXF1 expression in human primary colorectal cancers} We wished to confirm if RHOXF1 is expressed in human colorectal cancers, as reported by gene expression profiling [28]. We collected eight matched sets of specimens from patients with metastatic colorectal cancer. These tissues represented liver metastasis and matched normal liver tissues from eight patients. Total RNA was purified from these tissues, and the amounts of RHOXF1 mRNA were quantified by RT-qPCR (Figure 2). RHOXF1 mRNA was expressed in the normal liver tissues $(\mathrm{N})$, ranging from 122 to 558 copies relative to $1.0 \mathrm{E} 6$ copies of $\beta$-actin mRNA. In the tumor tissues $(\mathrm{T})$, RHOXF1 mRNA was also expressed in 7 out of 8 patients, ranging from 15 to 310 copies of mRNA.

\section{Correlation of Rhox $\mathbf{5}$ gene expression to the histone} epigenetic marks in the promoter region of the gene We sought to find a correlation between Rhox5 gene expression and its epigenetic marks in the promoter region (Table 2). Initially we examined histone modifications in ES and other cells by ChIP assays. In ES cells, there was a low level of H3K4me2 and higher levels of H3K27me3 and H3K9me2 marks on ChIP-1 region (Figure $3 \mathrm{~A})$. In $\mathrm{Pd}$ region (ChIP-2 region), the pattern was similar. This pattern of histone marks would correlate with the low level of expression seen in ES cells. In gene-silenced MNC and mammary epithelial cells, as P1Avell as P815 cancer cells with extremely low level of Rhox5 mRNA, they revealed high levels of H3K9me2 together with low levels of H3K27me3. The active marks were either undetectable or barely detectable (Figure 3A and Additional File 1). Interestingly, we did not detect H3K4me2, H3K27me3, and H3K9me2 marks on Rhox 5 Pd region in 4T1 cells, although a low level of mRNA was transcribed from Pd in these cells (Additional File 1).

We chose to compare the histone marks in two cancer cell lines with either the highest (CT26) or the lowest (EMT6) Rhox5 expression (Figure 3B \& C). The active marks (H3ac, H4ac, H3K9ac and H3K4me2) are high in CT26 cells, and very low in EMT6 cells. Interestingly, we detected relative high levels of repressive marks (H3K9me2 and H3K27me3) in both CT26 and EMT6 cells.

We have also paid attention to the "bivalent domain" chromatin structure in the promoter region. The H3 $\mathrm{K} 4 \mathrm{me} 2$ and $\mathrm{K} 27 \mathrm{me} 3$ bivalent marks exist not only in undifferentiated ES cells, but also in germline-tissue derived somatic cells (TM4) and some cancer cells (MOSEC, CT26 and MC38).

\section{Strong correlation of promoter DNA methylation with Rhox 5 gene expression}

We wished to determine DNA methylation status in the promoters of Rhox 5 gene in the same set of cell types. Both Pd and Pp promoters of the gene are CpG-poor and contain no $\mathrm{CpG}$ islands (GenBank accession: AF410462) [54]. Specific primers were selected to amplify bisulfite-treated genomic DNA from ten lines of cells including ES cells, somatic cells, and cancer cells. These primers covered DNA segments in the $\mathrm{Pd}, \mathrm{Pp}$, and translation start site (TSS) regions (BS-1, BS-2 and BS-3 regions, respectively), covering four CpG dinucleotides each (see Figure 1A). As shown in Figure 4 (A \& B), both ChIP-1 (Pd) and TSS regions were relatively hypermethylated in ES cells. As Rhox5 is expressed at a low level from Pd in ES cells, our results suggested that DNA hypermethylation and a moderately repressive pattern of histone epigenetic marks together dictated a low level of Rhox 5 expression. TM4 and MOSEC cells had similar epigenetic patterns as ES cells, and this also correlated with low level of Rhox 5 expression. For CT26 and MC38 cells that express high levels of Rhox5 gene, hypomethylated DNA was found in the promoter regions. Data from additional normal and cancer cells were presented in Additional File 2. The percentage of CpG methylation in the $\mathrm{Pd}$ region correlated quite well with the levels of Pd mRNA expression in the cells (Figure 4B). 


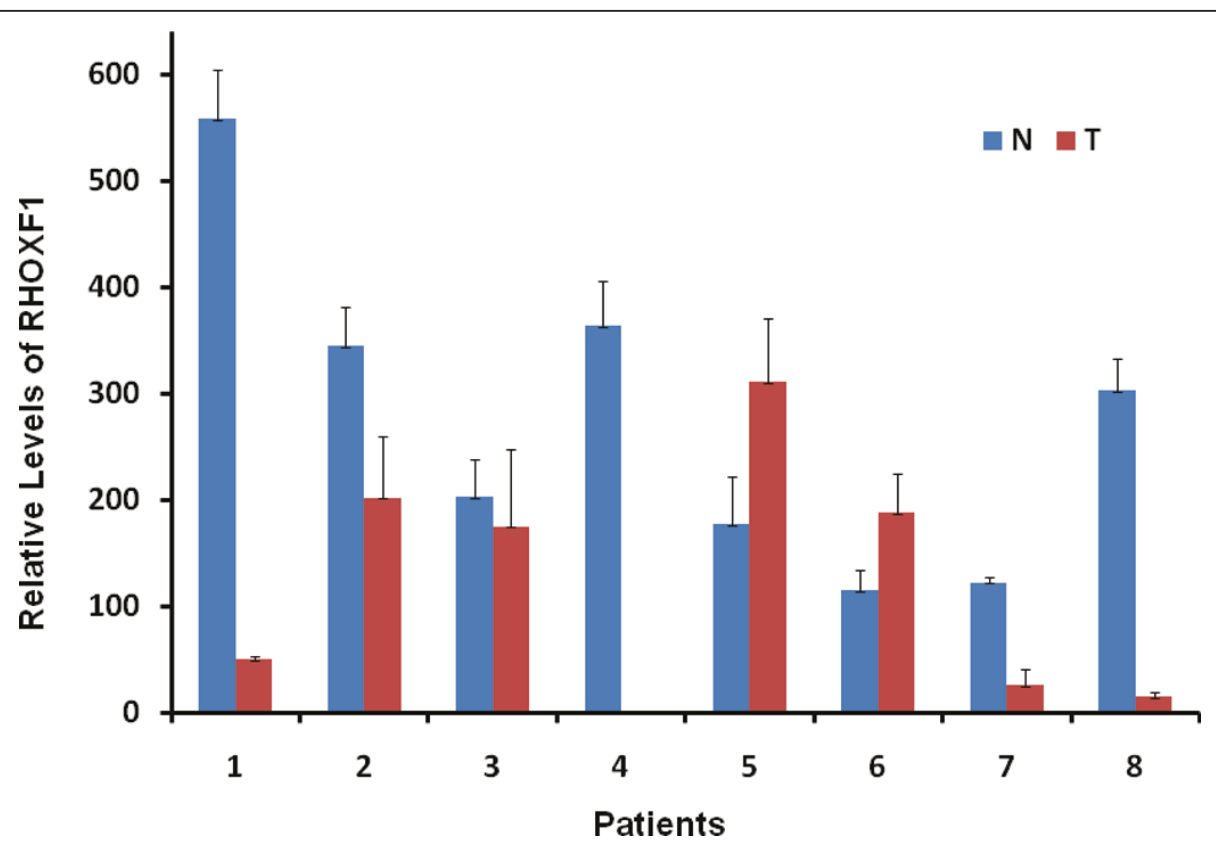

Figure 2 RhoxF1 mRNA expression in liver lesions of colorectal cancer and matched liver tissues from colorectal cancer patients. Total RNA from matched liver tissues $(\mathrm{N})$ and metastatic colorectal cancer $(\mathrm{T})$ was purified and RHOXF1 mRNA was quantified by RT-qPCR. Relative Rhox 5 mRNA levels were expressed as normalized to 1.0E6 copies of $\beta$-actin mRNA. Bars represent means with s.d. In patient 4, RHOXF1 mRNA from tumor (T) was below the level of detection.

Differentiation of F9 EC cells induced by epigenetic agents resulted in significant changes of histone marks A distinct characteristic of genes marked by a bivalent domain is that these genes can change expression levels rapidly during ES differentiation as bivalent marks are resolved to monovalent marks (H3K4me2 or H3K27me3 only), remain bivalent, or disappear altogether $[41,42,55]$. As a result we sought to study changing patterns of histone epigenetic marks during EC differentiation. The F9 EC cells can be induced to differentiate with upregulation of Rhox 5 mRNA by retinoic acid
(RA), RA plus cAMP, or valproic acid. All these agents exhibit properties of epigenetic modulators $[8,56,57]$. The HDAC inhibitor MS-275 can induce p21-dependent growth arrest and differentiation of human leukemia cells at lower doses [58]. We demonstrated that both MS-275 and RA treatment induced Rhox5 mRNA 3-fold by $72 \mathrm{~h}$, and RA plus cAMP could induce Rhox 5 20-25fold in 5 days (Figure 5A). These differentiated cells displayed dramatically reduced tumorigenicity in nude mice (Additional File 3). In undifferentiated F9 EC cells, the Pd promoter was marked with low levels of K4me2,

Table 2 Summary of locations of key data from various cells

\begin{tabular}{|c|c|c|c|}
\hline Primary Cells or Cell Lines & RT-PCR & Bisulfite Sequencing & ChIP Assay \\
\hline ES Cells & Fig. 1 & Fig. 4 & Fig. 3 \\
\hline Sertoli cells (TM4) & Fig. 1 & Fig. 4 & Fig. 3 \\
\hline Mononucleocytes (MNC) & Fig. 1 & Fig. 4 & Fig. 3 \\
\hline CT26 (colon cancer) & Fig. 1 & Fig. 4 & Fig. 3 \\
\hline MC38 (colon cancer) & Fig. 1 & Fig. 4 & Fig. 3 \\
\hline 4T1 (mammary cancer) & Fig. 1 & Fig. 4 & AF. 1 \\
\hline EMT6 (mammary cancer) & Fig. 1 & Fig. 4 & Fig. 3; Fig. 5 \\
\hline P815 cells (mastocytoma) & Fig. 4 & AF. 2 & Fig. 5; AF. 1 \\
\hline EMT6 \& P815 cells treated with epigenetic drugs & Fig. 4 & n.d. & Fig. 5 \\
\hline F9 (embryonic carcinoma) & Fig. 1; Fig. 5 & n.d. & Fig. 5 \\
\hline MOSEC (ovarian cancer) & Fig. 1; Fig. 6 & Fig. 4 & Fig. 3 \\
\hline MOSEC SP & Fig. 6 & n.d. & Fig. 6 \\
\hline
\end{tabular}




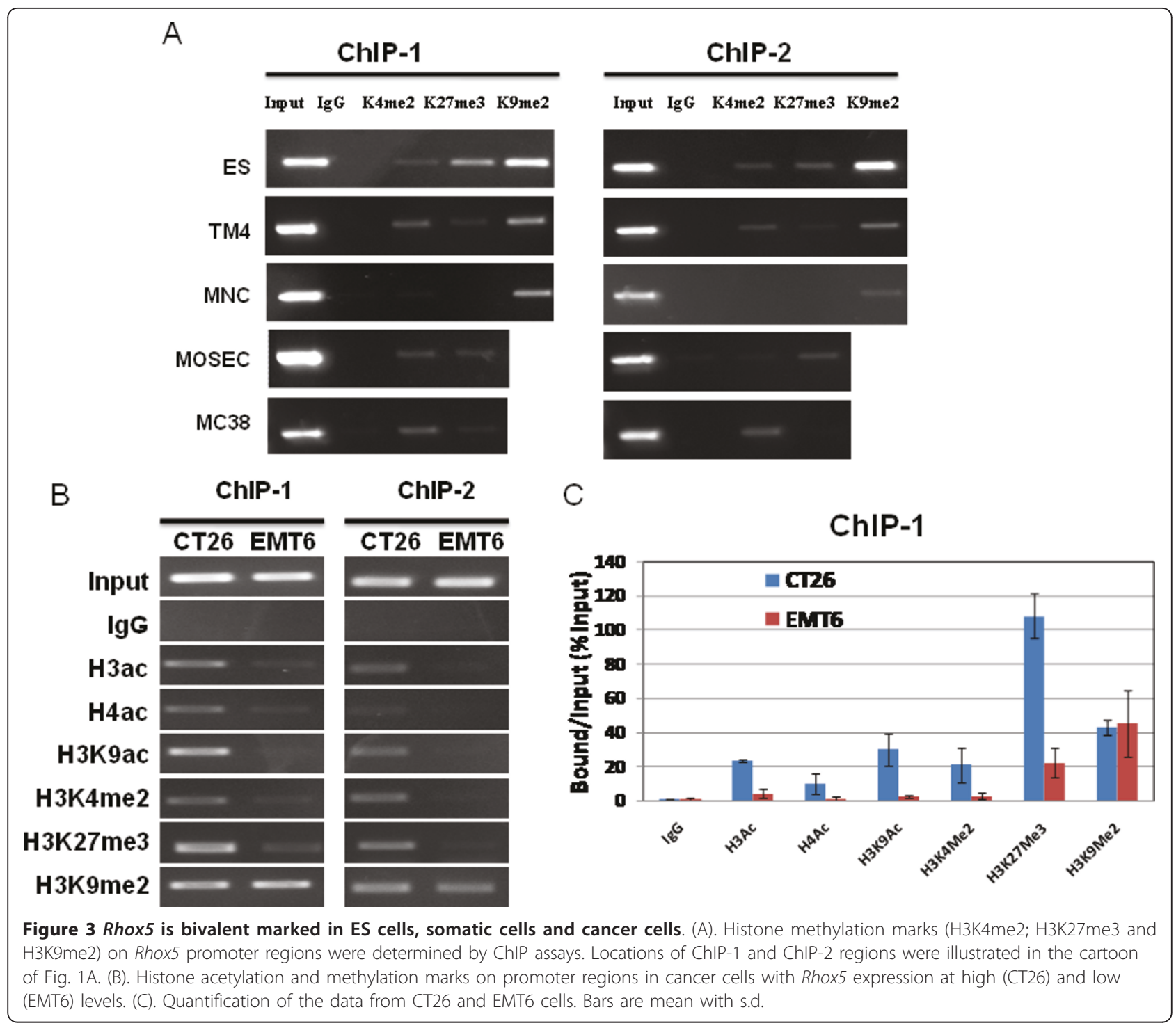

but higher levels of K27me3 and K9me2 (Figure 5B). Upon induced differentiation by either drug, K27me3 disappeared and K4me2 was reduced ( $<0.05)$, while K9me2 was not significantly affected.

Rhox 5 induction in silenced cancer cells by epigenetic drugs via increased permissive and decreased repressive marks

We sought to study the dynamic changes of histone marks along with Rhox 5 gene induction in cancer cells treated with DAC or MS-275. CA07/A, EMT6 and P815 cancer cells express very low levels of Rhox 5 mRNA (Figure 1 and Table 1). Upon treatment with decitabine (DAC) or MS-275, Rhox5 mRNA was significantly upregulated, ranging from 40 to 3000-fold (Figure 5C). We then analyzed the histone marks in the $\mathrm{Pd}$ in cancer cells without or with drug treatment (Figure 5D). In mock-treated EMT6 and P815 cancer cells, there were elevated levels of H3K9me2, very low levels of H3K27me3, and undetectable levels of H3K4me2. After drug treatment, significant induction in $\mathrm{H} 3 \mathrm{~K} 4 \mathrm{me} 2$ and reduction in $\mathrm{H} 3 \mathrm{~K} 9 \mathrm{me} 2$ was observed, yet $\mathrm{H} 3 \mathrm{~K} 27 \mathrm{me} 3$ remained low or reduced.

Rhox5 was expressed in SP and NSP of cancer cells with bivalent histone marks

We next examined whether Rhox 5 was expressed in cancer stem (CS)/progenitor cells and whether there was an associated bivalent chromatin pattern. The SP from primary cancers and cancer cell lines has been shown to be enriched for CS/progenitor cells [59]. Hoechst 33342 dye exclusion was performed with verapamil as a specific inhibitor of H33342 transport in order to identify SP. We initially chose CT26 colorectal 


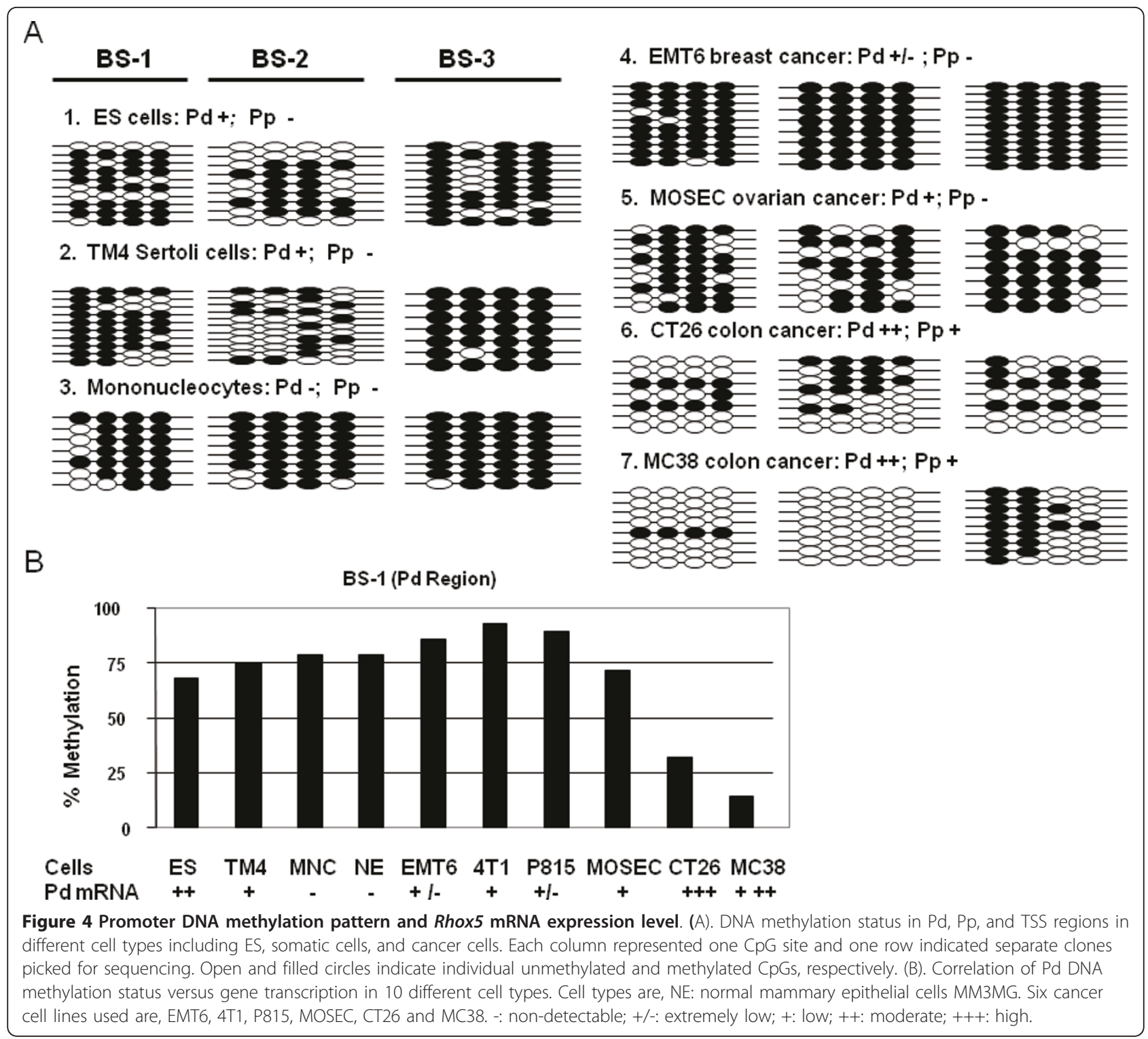

cancer cells and showed that there was a small fraction of SP $(\sim 1 \%)$ and that Rhox 5 was expressed in both SP and NSP (data not shown). Due to the number of SP cells needed to properly perform the ChIP assays, it was difficult to obtain sufficient SP cells from this colorectal cancer cell line. Thus we utilized ovarian cancer cells because ovarian cancer cells contain a relatively large SP that is enriched for CS/progenitor cells [60]. Indeed we showed that the MOSEC ovarian cancer cell line contained $9.7 \%$ of SP and that this population could be blocked by verapamil (Figure 6A). RT-qPCR demonstrated that SP expressed Rhox 5 mRNA about 3-fold higher than NSP from MOSEC cancer cells (Figure 6B). We examined the possibility of Rhox 5 upregulation in SP by the epigenetic drug MS-275. There was a 3 4fold induction of Rhox 5 mRNA in both the original
MOSEC and NSP cells by MS-275. However, there was no significant up-regulation of Rhox5 in MS-275-treated SP cells (Figure 6B). We also examined two key histone marks (K4me2 and $\mathrm{K} 27 \mathrm{me} 3$, the bivalent marks) and found that the Pd promoter was marked by both K4me2 and $\mathrm{K} 27 \mathrm{me} 3$ in both SP and NSP from MOSEC cells. As expected, MS-275 treatment did little to change the pattern of these two histone epigenetic marks in SP cells (Figure 6C).

Rhox5 knockdown attenuated cell proliferation and cell migration in vitro and tumor growth in vivo Little is known concerning Rhox 5 function in cancer cells. Therefore we wished to explore the functions of Rhox 5 in cancer cells. We selected a colon cancer model (CT26) for Rhox 5 functional analyses since our initial 


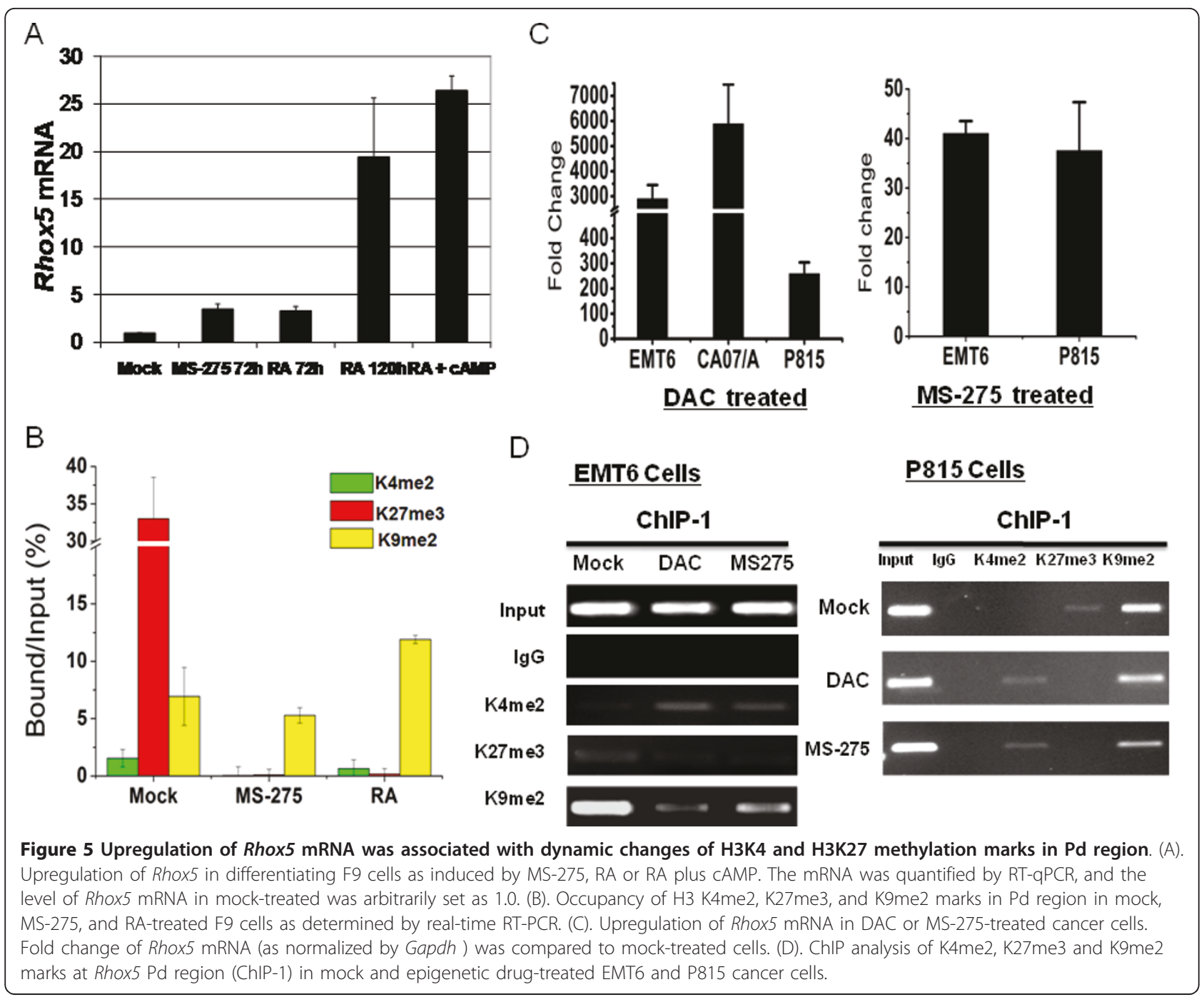

results indicated that CT26 cells express a high level of Rhox5 mRNA.

We used lentivirus-mediated shRNA against Rhox 5 to knockdown the expression of this gene. As shown in Figure 7A, shRNA clone 49 demonstrated a higher knockdown efficiency than clone 48 (80\% versus $50 \%)$ as determined by RT-qPCR. Western blot analysis confirmed that Rhox 5 protein was greatly reduced in clone 49 (Figure 7B). We chose clone 49 for further characterization in vitro and in vivo. Cell proliferation was significantly decreased at 72 and $96 \mathrm{~h}$ following knockdown compared to the parental CT26 cells and corresponding control lentiviral vector transduced (CTV) CT26 cells (p $<0.05$ ) (Figure 7C). Cell migration ability in clone 49 cells was also significantly reduced $(\mathrm{p}<0.05$; compared to CT26 and CTV, respectively) (Figure 7D). We further examined the property of tumor growth from shRNA knockdown and parental CT26 cells in a subcutaneous tumor model in athymic nude mice. Tumor growth was slower over time in mice inoculated with clone 49 compared to those with parental CT26 cancer cells or CTV CT26 cells. At the time of sacrifice (day 19), both tumor volumes and tumor weights were significantly reduced in the clone 49 group compared to the two control groups $(\mathrm{p}<0.05)$ (Figure $7 \mathrm{E})$.

\section{Discussion}

The Rhox gene cluster is essential for development, and three members (Rhox2, Rhox4 and Rhox 5 ) have important functions for pluripotency of ES cells. In a recent study, it has been demonstrated that Rhox 2 and Rhox4 genes, both expressed at low levels in ES cells, are marked by neither K4 nor K27 trimethylation of histone H3 in ES cells [61]. This suggests that DNA methylation is one of the major repressive mechanisms for those genes that lack both H3 K4/K27 trimethylations. Previous studies suggest that DNA methylation is involved in Rhox5 gene regulation, yet histone modifications 


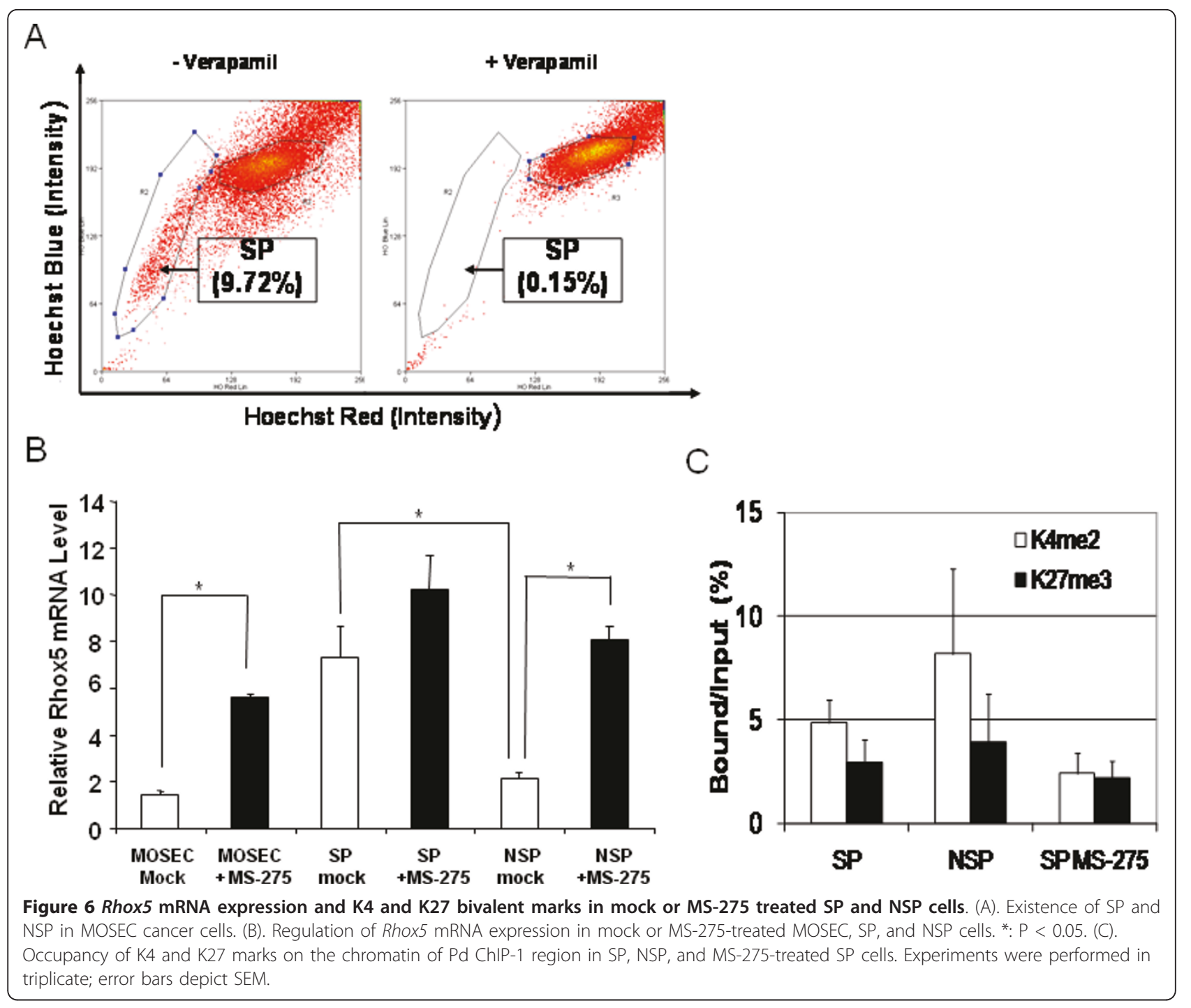

around the promoter region of the gene in correlation to gene expression have not been examined.

In this study, we undertook the task of analyzing the epigenetic marks in the Rhox 5 gene promoter region, and we related these modifications to Rhox 5 expression levels in ES cells, germline-tissue-derived Sertoli cells, cancer cells, and cancer stem/progenitor cells, as well as Rhox5 -silenced somatic cells. We had three main goals in mind. First, we wanted to examine both DNA methylation patterns and histone marks around the promoter region to determine if the epigenetic patterns would correlate with Rhox 5 expression in those cells. Second, we wish to examine whether the "bivalent domain" epigenetic feature originally identified in key developmental genes in ES cells also existed in the Rhox5 gene in both ES cells and other types of cells such as cancer stem cells. Finally, since Rhox 5 is expressed in most, if not all, of the cancer cell lines and in colorectal cancer in vivo, it was of great interest to begin to uncover its potential function in cancer.

The general conclusion from our current study is that the sum of both active and repressive epigenetic marks together dictates the levels of Rhox 5 mRNA expression in a particular cell type or cell line. DNA hypermethylation together with repressive histone modifications dictate the silencing or extreme reduction in Rhox5 expression in normal mononucleocytes (MNC) or EMT6 cancer cells. In cells expressing low levels of Rhox 5 such as ES cells, F9 cells, and TM4 cells, DNA is moderately methylated, and the histone epigenetic marks profile shifted to a more neutral state. These cells displayed both active marks and repressive marks, even though the exact marks and levels of these marks varied from one cell type to another. The existence of a "bivalent domain" represents such an epigenetic feature in these cells. In cells (CT26 and MC38) with high levels 


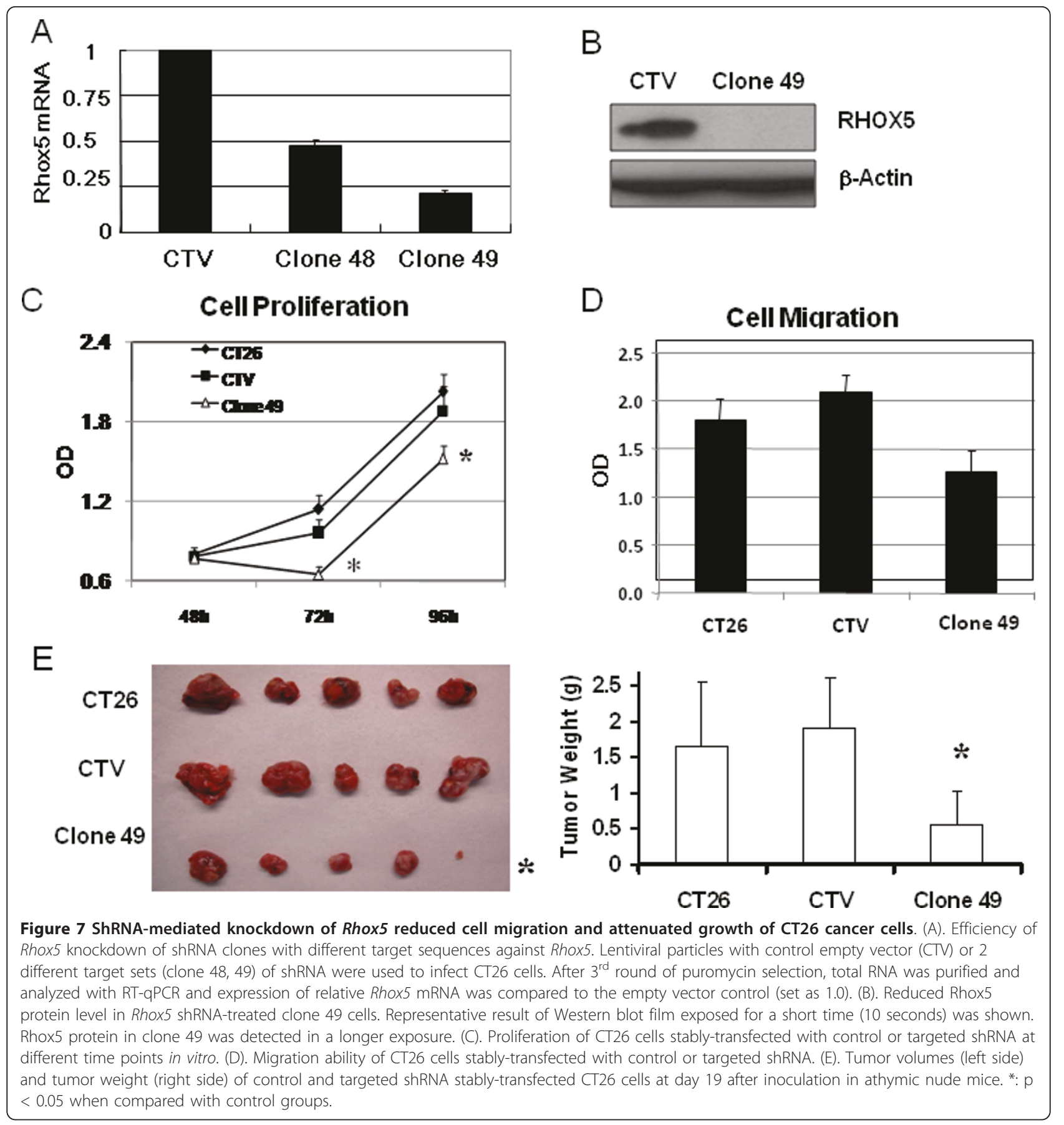

of Rhox 5 expression, DNA is hypomethylated, and the active histone marks are also elevated, consistent with high levels of Rhox 5 mRNA. Surprisingly, we also detected high levels of repressive histone marks.

We found the "bivalent domain" chromatin epigenetic structure in the Rhox 5 promoter not only in ES cells and SP cells enriched for cancer stem/progenitor cells, but also in cancer cells and fully differentiated germline tissue-derived somatic Sertoli cells. Our study is not the first to show that the bivalent chromatin signature is present in somatic cells. Roh et al. have shown that about $59 \%$ of gene promoters studied in primary human $\mathrm{T}$ cells contain bivalent marks [62]. In the human foreskin fibroblast BJ cell line, bivalent marks exist in some lineage specific genes [63]. In cancer cells, SFRP and GATA genes are marked by a bivalent chromatin domain, and the authors defined this as a "stem cell-like chromatin structure" [60]. For Rhox5, we also found this 
stem cell-like chromatin structure in three cancer cell lines (CT26, MC38 and MOSEC). Populations of cancer cells are heterogeneous and contain only a small number of cancer stem cells that possess the capacity to maintain self-renewal and undifferentiated status. We further sorted two cell populations (SP and NSP) from MOSEC cells. Surprisingly, both fractions of cells contain the bivalent domain in the Rhox 5 gene promoter.

One of our initial aims was to induce differentiation of CS/progenitor cells by HDAC inhibitors [64], in order to examine Rhox 5 gene expression during differentiation and to explore this as a potential therapeutic approach. F9 EC cells are considered by many to be the malignant stem cells of teratocarcinoma [65]. We have confirmed that F9 cells can be differentiated into "normal cells" by epigenetic drugs such as RA and MS-275. Upon such an induction of differentiation these cells display a benign phenotype as the tumor formation in nude mice was retarded. The Rhox5 gene was upregulated and the bivalent marks disappeared or were greatly reduced. This is consistent with findings by other investigators that a fairly large group of active genes contain neither of the two histone marks $[40,66]$. The remodeling of these histone marks in the promoter may be related to the differentiation status and/or particular cell type after induction of differentiation.

When MS-275 was applied to the CS/progenitorenriched SP cells from MOSEC ovarian cancer, it failed to up-regulate Rhox 5 and did not reduce the bivalent chromatin pattern in the gene. In this and other studies, SP cells were isolated based on the property of high levels of ABCG2 pump molecule capable of mediating the active efflux of numerous anticancer drugs and the dye Hoechst [59]. These SP cells could mediate the efflux of MS-275 similar to what occurs with other drugs. This might explain why SP cells failed to respond to MS-275-induced cell differentiation.

We showed that Rhox 5 knockdown by shRNA in CT26 colon cancer decreased cell migration and cell proliferation in vitro and tumor growth in vivo. This is reminiscent of the previous results that targeted disruption of Rhox 5 increased male germ cell apoptosis and reduced sperm production, sperm motility, and fertility [12]. What are the downstream molecules and how does Rhox 5 knockdown affect downstream signaling in cancer? One gene directly targeted by Rhox 5 is Unc5c, a tumor suppressor frequently silenced by DNA methylation in colon cancer $[21,67]$. In CT26 colon cancer cells, Unc5c is not expressed, and Rhox 5 knockdown by shRNA did not change Unc5c expression (data not shown). Instead, the attenuated CT26 cancer growth and migration by Rhox 5 knockdown may be mediated by Ras-ERK signaling pathway. Evidence for this could be found in a colon adenoma model induced by conditional activation of $\mathrm{K}$-ras ${ }^{\mathrm{V} 12}$ in $M s h 2$ knockout mice in which Rhox 5 is one of three genes significantly upregulated [17]. Interestingly, P1A, another epigenetically regulated and $\mathrm{X}$-linked cancer-germline gene we have studied previously [35], was also upregulated in this $\mathrm{K}-\mathrm{ras}^{\mathrm{V} 12} / \mathrm{Cre} / / M$ sh 2 - tumor model. A recent study showed that ectopic expression of Rhox 5 in cancer cells induced a significantly increased extracellular signalregulated kinase (ERK) activity and multiple resistance to various apoptotic pressures [23]. In addition, it has been shown that Ras signaling activates Rhox 5 transcription through its Pd promoter [68]. Oncogenic Ras signaling also induces tumor promoting genes and directs epigenetic inactivation of tumor suppressor genes $[69,70]$. Another downstream component of the Ras signaling pathway, NF- $\kappa \mathrm{B}$, promotes breast cancer cell migration and thus metastasis by inducing chemokine receptor CXCR4 [71]. Therefore, our finding that Rhox5 knockdown attenuated tumor cell growth and cell migration fits a hypothetic Ras tumor promoting signaling pathway in which ERK1/2, NF- $\kappa \mathrm{B}$, and Rhox5 function downstream. Further studies will shed more light on Rhox 5 function in precancerous lesions and in cancer progression of colon malignancy. In addition, Rhox 5 is widely expressed in cancer cells and cancer stem/progenitor cells, and can be selectively induced or suppressed by epigenetic agents. Thus, Rhox 5 could serve as an ideal target for therapeutic interventions including shRNA therapy, cancer immunotherapy, and epigenetic therapy.

The closely related human gene RHOXF1 has been shown to be expressed in ES cells and adult germline stem cells, some established cancer lines and in primary metastatic colorectal cancer. Its expression pattern is consistent with potential roles in ES cells, adult tissue stem cells, and possibly cancer stem cells, despite the fact that we know little, if any, of its biological functions. Efforts to elucidate the functions of RHOXF1 in the biology of cancer and reproduction and to explore RHOXF1 as a potential therapeutic target should be undertaken.

\section{Methods}

\section{Cell culture and human tissues}

Many cancer cell lines have been used in our previous studies $[15,35]$. The F9 EC cells were obtained from the American Type Culture Collection (Manassas, VA). In order to maintain F9 undifferentiated status, F9 cells were grown on gelatin-coated tissue culture plates. All cells were cultured in the recommended culture media supplemented with $5 \%$ or $10 \%$ fetal bovine serum (FBS), plus penicillin and streptomycin.

Undifferentiated mouse ES cells (genotype 129*129, passage 18) were purchased from Open Biosystems 
(Huntsville, AL). They were used directly for analysis of gene expression, bisulfite sequencing, and ChIP assays.

The specimens of human colorectal cancer and matched normal tissues were collected under the UPCI protocol \# 02-077, with consent of the patients.

\section{Flow cytometry}

To identify and isolate the side population and non-side population cell fractions, cancer cells were harvested, washed, and suspended at 1.0E6 cells $/ \mathrm{ml}$ in Hanks balanced salt solution (HBSS) (Invitrogen, Carlsbad, CA) as described [72]. The cells were labeled with Hoechst 33342 (Invitrogen) at a concentration of $5.0 \mu \mathrm{g} / \mathrm{ml}$ in the absence and presence of $50 \mu \mathrm{M}$ verapamil (Sigma, St. Louis, MO). The labeled cells were incubated for 90 min at $37^{\circ} \mathrm{C}$. After washing with HBSS once, the cells were counterstained with $1.0 \mu \mathrm{g} / \mathrm{ml} 7$-AAD (Becton Dickinson, Franklin Lakes, NJ) to label dead cells. The cells were analyzed by using a MoFlo cell sorter (Beckman Coulter, Fort Collins, CO).

\section{Drug treatment}

Rhox 5 gene induction was performed by treating cancer cells with 5-aza-2-deoxycytidine (DAC, $2.0 \mu \mathrm{M}$ for $48 \mathrm{~h})$ or MS-275 (2.0 $\mu \mathrm{M}$ for $72 \mathrm{~h})$ [15]. Cells were plated in $100 \mathrm{~mm}$ culture plates to obtain $\sim 20 \%$ confluence. After overnight incubation, cells were treated daily with drugs at different concentrations for 48 $72 \mathrm{~h}$. To induce differentiation, F9 cells were cultured in gelatinized plates in the presence of $0.1 \mu \mathrm{M}$ retinoic acid (RA) (Sigma) or RA plus $1.0 \mathrm{mM}$ cAMP (Sigma) as described [8].

\section{RNA isolation, RT-PCR and RT-qPCR}

Total RNA purification, RT-PCR, and RT-qPCR were performed as described previously [15]. RT-qPCR was performed with an ABI StepOnePlus real-time PCR system (Applied Biosystems, Foster City, CA). The copy numbers of mRNA were determined with relative quantitation by the comparative $\mathrm{Ct}$ method using the software with the machine.

\section{Western blot analysis}

Western blot analysis was performed as described [15]. Briefly, protein extract was prepared from tumor cells and from ovary and testis tissues of BALB/c mice. Twenty micrograms of protein was resolved on $12 \%$ SDS polyacrylamide gels and transferred to immobilonP PVDF membrane (Millipore, Billerica, MA). The resulting blots were blocked with 5\% nonfat dry milk and probed with antibodies specific for Rhox5 (Abcam, Cambridge, MA) and $\beta$-actin (Sigma).

\section{Isolation of genomic DNA and bisulfite sequencing}

Genomic DNA from cell lines was extracted using a QIAamp DNA mini kit (Qiagen, Volencia, CA). DNA from spleen mononucleocytes (MNC) of a BALB/c mouse was extracted using a DNeasy Tissue kit (Qiagen). Bisulfite modification of DNA, subcloning, and sequencing of converted DNA were performed as described [15].

\section{Chromatin immunoprecipitation (ChIP) assay and real- time PCR}

ChIP assays were performed using EZ-ChIP kits (Millipore, Billerica, MA) [15]. The following ChIP-grade antibodies were used: anti-acetyl histone $\mathrm{H} 3$ [H3ac] and anti-acetyl histone $\mathrm{H} 4$ [H4ac] (Millipore), anti-acetyl histone $\mathrm{H} 3$ lysine 9 [H3K9ac], anti-dimethyl histone H3 lysine 4 [H3K4me2], anti-dimethyl histone $\mathrm{H} 3$ lysine 9 [H3K9me2], anti-trimethyl histone $\mathrm{H} 3$ lysine 27 [H3K27me3], and an isotype control IgG (All from Abcam). In earlier experiments, histone $3 \mathrm{~K} 4, \mathrm{~K} 27$, and K9 methylation in the ChIP-1 region was quantified by semi-quantitative PCR gel density analysis. In all later experiments, real-time PCR was used to quantify the amounts of DNA fragment in the ChIP assays. Specific primer sets were designed to amplify Rhox 5 gene ChIP1 (Pd) and ChIP-2 (Pp) regions. Most primer sequences are listed in Additional File 4. For Rhox 5 Pd real-time PCR, $2.0 \mu \mathrm{l}$ of DNA was added to PCR reaction systems using a QuantiTect SYBR Green PCR kit (Qiagen). We performed quantitative PCR data analysis of ChIP assay using a formula described in the User Manual of ChampionChIPTM kits (SA Biosciences, Frederick, MD, USA). Briefly, we normalized each ChIP DNA fractions' Ct value to the Input DNA fraction $\mathrm{Ct}$ value for the same qPCR Assay $(\triangle \mathrm{Ct})$ to account for chromatin sample preparation differences. Then we reported ChIP-qPCR results as a "\% Input" for characterizing individual experimental samples.

\section{ShRNA-mediated knockdown of Rhox5 gene}

Four different lentivirus particles with target shRNA against Rhox 5 were ordered from Sigma. The best result for knockdown was obtained from clone 49. The shRNA clone 48 sequence is, CCGGAGTGCAGAATTGGTTTAAGATCTCGAGATCTTAAACCAATTCTG-

CACTTTTTTG. The shRNA clone 49 sequence is, CCGGCAGCGCACTAATTCCTTTGATCTCGAGATCAAAGGAATTAGTGCGCTGTTTTTG). A lentivirus with the corresponding empty plasmid vector (CTV) was used as non-target control. Lentivirus with Rhox 5 target and non target shRNA was used to infect CT26 cells at MOI of 1.0. After three rounds of puromycin 
$(6.0 \mu \mathrm{g} / \mathrm{ml})$ selection, stably transduced CT26 cells were selected and Rhox 5 knockdown was assessed by both real-time RT-PCR and Western blot analysis.

\section{Cell proliferation and cell migration assays}

For cell proliferation assays, 1,000 CT26 cancer cells in $10 \%$ FBS-containing DMEM medium were added to each well of a 96-well plate. Cell proliferation was determined by using CellTiter 96 AQueous Non-Radioactive Cell Proliferation Assay Kit (Promega, Madison, WI). The reagent was added directly to culture wells, and following incubation for $4 \mathrm{~h}$ at $37^{\circ} \mathrm{C}$, absorbance at 490 $\mathrm{nm}$ was measured using a 96 -well plate reader. For trans-well migration assays, $1 \times 10^{5}$ serum starved cells in serum-free medium were added to the top chambers of 24-well trans-well plates (Cell Biolabs, San Diego, CA), and growth media containing 10\% FBS was added to the bottom chambers. After $12 \mathrm{~h}$ of incubation, migrating cells were stained, and absorbance was recorded at $560 \mathrm{~nm}$. Assays were done in triplicates, and the data are presented as the average absorbance of cells.

\section{In vivo tumor growth}

Athymic nude mice were ordered from Tacomic Farms, Inc. (Germantown, NY). Mice were housed in standard conditions and given food and water ad libitum. The animal study was approved by the Institutional Animal Care and Use Committee of the University of Pittsburgh.

Rhox5 and control shRNA lentivirus-stably-transduced CT26 colon cancer cells were injected subcutaneously into hind frank of 5-6 weeks old athymic nude mice (1.0E5 cells per mouse, 5 mice per group). Mice were closely monitored until any one animal possessed a tumor of 2.0 centimeter in diameter. At this time point, tumor volumes of all mice were measured, and mice were sacrificed.

\section{Statistical analysis}

Statistical analysis was calculated using Microsoft Excel or SPSS software. Significance was calculated using Student's $t$-test.

\section{Additional material}

Additional file 1: The results of ChIP assays with Rhox5 promoter regions in MM3MG, P815 and 4T1 cells. The ChIP assays were performed as those in Figure 2. Shown are one mammary fibloblast (MM3MG) and two cancer cell lines.

Additional file 2: DNA methylation analysis in ChIP-1 and ChIP-2 regions of the gene from MM3MG mammary epithelial cells and P815 cancer cells. Data of DNA methylation analysis in Rhox5 ChIP-1 and ChIP-2 regions are presented. The details are in Figure 3.
Additional file 3: Growth of F9 embryonic carcinoma in nude mice Tumor growth in nude mice, inoculated with mock-treated F9 cells (left frank) or MS-275-treated F9 cells (right frank).

Additional file 4: PCR primers used for PCR assays.

\section{Acknowledgements}

This work was supported in part by David C. Koch Regional Therapy Cancer Center. We would like to thank anonymous reviewers for their valuable comments on the manuscript, Dr. Tao Cheng and Dr. Guan Jin for helpful discussions, Dr. Magesh Sathaiah for assistance in data processing for figure 2, and Mr. E. Michael Meyer for assistance in flow cytometry.

\section{Author details}

${ }^{1}$ The University of Pittsburgh Cancer Institute, University of Pittsburgh, Pennsylvania 15213, USA. ${ }^{2}$ Department of Surgery, University of Pittsburgh School of Medicine, Pittsburgh, Pennsylvania 15213, USA.

\section{Authors' contributions}

QL participated in all phases of the project, carried out the majority of the experiments, analyzed the data, and assisted in writing the manuscript. MEO participated in the animal experiments and assisted in editoring the manuscript. DLB participated in the design of this study. ZSG conceived and designed the experiments, and assisted in writing the manuscript. All authors read and approved the final manuscript.

\section{Competing interests}

The authors declare that they have no competing interests.

Received: 18 March 2010 Accepted: 24 May 2011

Published: 24 May 2011

\section{References}

1. MacLean JA, Wilkinson MF: The Rhox genes. Reproduction 2010, 140:195-213

2. Jackson M, Baird JW, Cambray N, Ansell JD, Forrester LM, Graham GJ: Cloning and characterization of Ehox, a novel homeobox gene essential for embryonic stem cell differentiation. J Biol Chem 2002, 277:38683-38692.

3. Fan Y, Melhem MF, Chaillet JR: Forced expression of the homeoboxcontaining gene Pem blocks differentiation of embryonic stem cells. Dev Biol 1999, 210:481-496.

4. Jackson M, Watt AJ, Gautier P, Gilchrist D, Driehaus J, Graham GJ, Keebler J, Prugnolle F, Awadalla P, Forrester LM: A murine specific expansion of the Rhox cluster involved in embryonic stem cell biology is under natural selection. BMC Genomics 2006, 7:212.

5. Bonner $A E$, Wang $Y$, You M: Gene expression profiling of mouse teratocarcinomas uncovers epigenetic changes associated with the transformation of mouse embryonic stem cells. Neoplasia 2004, 6:490-502.

6. Cinelli P, Casanova EA, Uhlig S, Lochmatter P, Matsuda T, Yokota T, Rulicke T, Ledermann B, Burki K: Expression profiling in transgenic FVB/N embryonic stem cells overexpressing STAT3. BMC Dev Biol 2008, 8:57.

7. Kobayashi S, Isotani A, Mise N, Yamamoto M, Fujihara Y, Kaseda K, Nakanishi T, Ikawa M, Hamada H, Abe K, Okabe M: Comparison of gene expression in male and female mouse blastocysts revealed imprinting of the X-linked gene, Rhox5/Pem, at preimplantation stages. Curr Biol 2006, 16:166-172.

8. Sasaki AW, Doskow J, MacLeod CL, Rogers MB, Gudas LJ, Wilkinson MF: The oncofetal gene Pem encodes a homeodomain and is regulated in primordial and pre-muscle stem cells. Mech Dev 1991, 34:155-164.

9. Maclean JA, Bettegowda A, Kim BJ, Lou CH, Yang SM, Bhardwaj A, Shanker S, Hu Z, Fan Y, Eckardt S, McLaughlin KJ, Skoultchi Al, Wilkinson MF: The Rhox homeobox gene cluster is imprinted and selectively targeted for regulation by histone $\mathrm{h} 1$ and DNA methylation. Mol Cell Biol 2011, 31:1275-1287.

10. Shanker $\mathrm{S}, \mathrm{Hu} Z$, Wilkinson MF: Epigenetic regulation and downstream targets of the Rhox5 homeobox gene. Int J Androl 2008, 31:462-470. 
11. Ivanova N, Dobrin R, Lu R, Kotenko I, Levorse J, DeCoste C, Schafer X, Lun Y, Lemischka IR: Dissecting self-renewal in stem cells with RNA interference. Nature 2006, 442:533-538.

12. Maclean JA, Chen MA, Wayne CM, Bruce SR, Rao M, Meistrich ML, Macleod C, Wilkinson MF: Rhox: a new homeobox gene cluster. Cell 2005, 120:369-382.

13. Wilkinson MF, Kleeman J, Richards J, MacLeod CL: A novel oncofetal gene is expressed in a stage-specific manner in murine embryonic development. Dev Biol 1990, 141:451-455.

14. Ono T, Sato S, Kimura N, Tanaka M, Shibuya A, Old LJ, Nakayama E: Serological analysis of BALB/C methylcholanthrene sarcoma Meth A by SEREX: identification of a cancer/testis antigen. Int J Cancer 2000, 88:845-851.

15. Li Q, Bartlett DL, Gorry MC, O'Malley ME, Guo ZS: Three epigenetic drugs up-regulate homeobox gene Rhox 5 in cancer cells through overlapping and distinct molecular mechanisms. Mol Pharmacol 2009, 76:1072-1081.

16. Paoni NF, Feldman MW, Gutierrez LS, Ploplis VA, Castellino FJ: Transcriptional profiling of the transition from normal intestinal epithelia to adenomas and carcinomas in the APCMin/+ mouse. Physiol Genomics 2003, 15:228-235

17. Luo F, Brooks DG, Ye H, Hamoudi R, Poulogiannis G, Patek CE, Winton DJ, Arends MJ: Conditional expression of mutated K-ras accelerates intestinal tumorigenesis in Msh2-deficient mice. Oncogene 2007, 26:4415-4427.

18. Lemmens $I H$, Forsberg $L$, Pannett AA, Meyen E, Piehl F, Turner JJ, Van de Ven WJ, Thakker RV, Larsson C, Kas K: Menin interacts directly with the homeobox-containing protein Pem. Biochem Biophys Res Commun 2001, 286:426-431.

19. Guo F, Huang X, Li S, Sun L, Li Y, Li H, Zhou Y, Chu Y, Zhou T: Identification of prosaposin as a novel interaction partner for Rhox5. J Genet Genomics 2007, 34:392-399.

20. Guo F, Li YQ, Li SQ, Luo ZW, Zhang X, Tang DS, Zhou TH: Interaction of mouse Pem protein and cell division cycle 37 homolog. Acta Biochim Biophys Sin (Shanghai) 2005, 37:784-787

21. Hu Z, Shanker S, MacLean JA, Ackerman SL, Wilkinson MF: The Rhox5 homeodomain protein mediates transcriptional repression of the netrin1 receptor gene Unc5c. J Biol Chem 2008, 283:3866-3876.

22. Rao MK, Maiti S, Ananthaswamy HN, Wilkinson MF: A highly active homeobox gene promoter regulated by Ets and Sp1 family members in normal granulosa cells and diverse tumor cell types. J Biol Chem 2002, 277:26036-26045.

23. Kim SH, Kim KW, Kim JH, Noh KH, Bae HC, Lee TH, Kim TW: Pem renders tumor cells resistant to apoptotic cell death induced by a CD8+ T cellmediated immune response or anticancer drug treatment. Cancer Lett 2010, 293:181-188.

24. Visvader JE, Lindeman GJ: Cancer stem cells in solid tumours: accumulating evidence and unresolved questions. Nat Rev Cancer 2008, 8:755-768.

25. Geserick C, Weiss B, Schleuning WD, Haendler B: OTEX, an androgenregulated human member of the paired-like class of homeobox genes. Biochem J 2002, 366:367-375

26. Wayne CM, MacLean JA, Cornwall G, Wilkinson MF: Two novel human Xlinked homeobox genes, hPEPP1 and hPEPP2, selectively expressed in the testis. Gene 2002, 301:1-11.

27. Conrad S, Renninger M, Hennenlotter J, Wiesner T, Just L, Bonin M, Aicher W, Buhring HJ, Mattheus U, Mack A, Wagner HJ, Minger S, Matzkies M, Reppel M, Hescheler J, Sievert KD, Stenzl A, Skutella T: Generation of pluripotent stem cells from adult human testis. Nature 2008, 456:344-349

28. Pantaleo MA, Astolfi A, Nannini M, Paterini P, Piazzi G, Ercolani G, Brandi G, Martinelli G, Pession A, Pinna AD, Biasco G: Gene expression profiling of liver metastases from colorectal cancer as potential basis for treatment choice. Br J Cancer 2008, 99:1729-1734.

29. Skotheim RI, Lind GE, Monni O, Nesland JM, Abeler VM, Fossa SD, Duale N, Brunborg G, Kallioniemi O, Andrews PW, Lothe RA: Differentiation of human embryonal carcinomas in vitro and in vivo reveals expression profiles relevant to normal development. Cancer Res 2005, 65:5588-5598.

30. Reik W, Dean W, Walter J: Epigenetic reprogramming in mammalian development. Science 2001, 293:1089-1093.

31. De Carvalho DD, You JS, Jones PA: DNA methylation and cellular reprogramming. Trends Cell Biol 2010, 20:609-617.

32. Baylin SB: DNA methylation and gene silencing in cancer. Nat Clin Pract Oncol 2005, 2(Suppl 1):S4-11.
33. Esteller M: Epigenetic gene silencing in cancer: the DNA hypermethylome. Hum Mol Genet 2007, 16(Spec No 1):R50-59.

34. Cho B, Lee H, Jeong S, Bang YJ, Lee HJ, Hwang KS, Kim HY, Lee YS, Kang GH, Jeoung DI: Promoter hypomethylation of a novel cancer/testis antigen gene CAGE is correlated with its aberrant expression and is seen in premalignant stage of gastric carcinoma. Biochem Biophys Res Commun 2003, 307:52-63.

35. Guo ZS, Hong JA, Irvine KR, Chen GA, Spiess PJ, Liu Y, Zeng G, Wunderlich JR, Nguyen DM, Restifo NP, Schrump DS: De novo induction of a cancer/testis antigen by 5-aza-2'-deoxycytidine augments adoptive immunotherapy in a murine tumor model. Cancer Res 2006, 66:1105-1113.

36. Berger SL: The complex language of chromatin regulation during transcription. Nature 2007, 447:407-412.

37. Kouzarides T: Chromatin modifications and their function. Cell 2007 128:693-705.

38. Wang Z, Zang C, Rosenfeld JA, Schones DE, Barski A, Cuddapah S, Cui K, Roh TY, Peng W, Zhang MQ, Zhao K: Combinatorial patterns of histone acetylations and methylations in the human genome. Nat Genet 2008, 40:897-903.

39. McEwen KR, Ferguson-Smith AC: Distinguishing epigenetic marks of developmental and imprinting regulation. Epigenetics Chromatin 2010, 3:2.

40. Barski A, Cuddapah S, Cui K, Roh TY, Schones DE, Wang Z, Wei G, Chepelev I, Zhao K: High-resolution profiling of histone methylations in the human genome. Cell 2007, 129:823-837

41. Bernstein BE, Mikkelsen TS, Xie X, Kamal M, Huebert DJ, Cuff J, Fry B, Meissner A, Wernig M, Plath K, Jaenisch R, Wagschal A, Feil R, Schreiber SL, Lander ES: A bivalent chromatin structure marks key developmental genes in embryonic stem cells. Cell 2006, 125:315-326.

42. Pan G, Tian S, Nie J, Yang C, Ruotti V, Wei H, Jonsdottir GA, Stewart R, Thomson JA: Whole-genome analysis of histone $\mathrm{H} 3$ lysine 4 and lysine 27 methylation in human embryonic stem cells. Cell Stem Cell 2007, 1:299-312

43. Schlesinger $Y$, Straussman R, Keshet I, Farkash S, Hecht M, Zimmerman J, Eden E, Yakhini Z, Ben-Shushan E, Reubinoff BE, Bergman Y, Simon I, Cedar H: Polycomb-mediated methylation on Lys 27 of histone $\mathrm{H} 3$ pre-marks genes for de novo methylation in cancer. Nat Genet 2007, 39:232-236.

44. Widschwendter M, Fiegl H, Egle D, Mueller-Holzner E, Spizzo G, Marth C, Weisenberger DJ, Campan M, Young J, Jacobs I, Laird PW: Epigenetic stem cell signature in cancer. Nat Genet 2007, 39:157-158.

45. Ohm JE, McGarvey KM, Yu X, Cheng L, Schuebel KE, Cope L, Mohammad HP, Chen W, Daniel VC, Yu W, Berman DM, Jenuwein T, Pruitt K, Sharkis SJ, Watkins DN, Herman JG, Baylin SB: A stem cell-like chromatin pattern may predispose tumor suppressor genes to DNA hypermethylation and heritable silencing. Nat Genet 2007, 39:237-242.

46. Oda M, Yamagiwa A, Yamamoto S, Nakayama T, Tsumura A, Sasaki H, Nakao K, Li E, Okano M: DNA methylation regulates long-range gene silencing of an X-linked homeobox gene cluster in a lineage-specific manner. Genes Dev 2006, 20:3382-3394.

47. Jackson-Grusby L, Beard C, Possemato R, Tudor M, Fambrough D, Csankovszki G, Dausman J, Lee P, Wilson C, Lander E, Jaenisch R: Loss of genomic methylation causes p53-dependent apoptosis and epigenetic deregulation. Nat Genet 2001, 27:31-39.

48. Fan Y, Nikitina T, Zhao J, Fleury TJ, Bhattacharyya R, Bouhassira EE, Stein A, Woodcock CL, Skoultchi Al: Histone $\mathrm{H} 1$ depletion in mammals alters global chromatin structure but causes specific changes in gene regulation. Cell 2005, 123:1199-1212.

49. Loriot A, Reister S, Parvizi GK, Lysy PA, De Smet C: DNA methylationassociated repression of cancer-germline genes in human embryonic and adult stem cells. Stem Cells 2009, 27:822-824

50. Kaneko KJ, Rein T, Guo ZS, Latham K, DePamphilis ML: DNA methylation may restrict but does not determine differential gene expression at the Sgy/Tead2 locus during mouse development. Mol Cell Biol 2004, 24:1968-1982

51. Yu X, Guo ZS, Marcu MG, Neckers L, Nguyen DM, Chen GA, Schrump DS: Modulation of p53, ErbB1, ErbB2, and Raf-1 expression in lung cancer cells by depsipeptide FR901228. J Natl Cancer Inst 2002, 94:504-513.

52. Yu XD, Guo ZS: Epigenetic drugs for cancer treatment and prevention: mechanisms of action. BioMolecular Concepts 2010, 1:239-251.

53. Bhardwaj A, Rao MK, Kaur R, Buttigieg MR, Wilkinson MF: GATA factors and androgen receptor collaborate to transcriptionally activate the Rhox 5 homeobox gene in Sertoli cells. Mol Cell Biol 2008, 28:2138-2153. 
54. Barbulescu K, Geserick C, Schuttke I, Schleuning WD, Haendler B: New androgen response elements in the murine pem promoter mediate selective transactivation. Mol Endocrinol 2001, 15:1803-1816.

55. Cui K, Zang C, Roh TY, Schones DE, Childs RW, Peng W, Zhao K: Chromatin signatures in multipotent human hematopoietic stem cells indicate the fate of bivalent genes during differentiation. Cell Stem Cell 2009, 4:80-93.

56. Fazi F, Travaglini L, Carotti D, Palitti F, Diverio D, Alcalay M, McNamara S, Miller WH, Lo Coco F, Pelicci PG, Nervi C: Retinoic acid targets DNAmethyltransferases and histone deacetylases during APL blast differentiation in vitro and in vivo. Oncogene 2005, 24:1820-1830.

57. Werling U, Siehler S, Litfin M, Nau H, Gottlicher M: Induction of differentiation in F9 cells and activation of peroxisome proliferatoractivated receptor delta by valproic acid and its teratogenic derivatives. Mol Pharmacol 2001, 59:1269-1276.

58. Rosato RR, Almenara JA, Grant S: The histone deacetylase inhibitor MS275 promotes differentiation or apoptosis in human leukemia cells through a process regulated by generation of reactive oxygen species and induction of p21CIP1/WAF1 1. Cancer Res 2003, 63:3637-3645.

59. Zhou S, Schuetz JD, Bunting KD, Colapietro AM, Sampath J, Morris JJ, Lagutina I, Grosveld GC, Osawa M, Nakauchi H, Sorrentino BP: The ABC transporter Bcrp1/ABCG2 is expressed in a wide variety of stem cells and is a molecular determinant of the side-population phenotype. Nat Med 2001, 7:1028-1034.

60. Szotek PP, Pieretti-Vanmarcke R, Masiakos PT, Dinulescu DM, Connolly D, Foster R, Dombkowski D, Preffer F, Maclaughlin DT, Donahoe PK: Ovarian cancer side population defines cells with stem cell-like characteristics and Mullerian Inhibiting Substance responsiveness. Proc Natl Acad Sci USA 2006, 103:11154-11159.

61. Fouse SD, Shen $Y$, Pellegrini M, Cole S, Meissner A, Van Neste L, Jaenisch R, Fan G: Promoter CpG methylation contributes to ES cell gene regulation in parallel with Oct4/Nanog, PcG complex, and histone H3 K4/K27 trimethylation. Cell Stem Cell 2008, 2:160-169.

62. Roh TY, Cuddapah S, Cui K, Zhao K: The genomic landscape of histone modifications in human T cells. Proc Natl Acad Sci USA 2006, 103:15782-15787.

63. Golebiewska A, Atkinson SP, Lako M, Armstrong L: Epigenetic landscaping during hESC differentiation to neural cells. Stem Cells 2009, 27:1298-1308.

64. Botrugno OA, Santoro F, Minucci S: Histone deacetylase inhibitors as a new weapon in the arsenal of differentiation therapies of cancer. Cancer Lett 2009, 280:134-144.

65. Lehtonen $\mathrm{E}$, Laasonen A, Tienari J: Teratocarcinoma stem cells as a model for differentiation in the mouse embryo. Int J Dev Biol 1989, 33:105-115.

66. Ke XS, Qu Y, Rostad K, Li WC, Lin B, Halvorsen OJ, Haukaas SA, Jonassen I, Petersen K, Goldfinger N, Rotter V, Akslen LA, Oyan AM, Kalland KH: Genome-wide profiling of histone h3 lysine 4 and lysine 27 trimethylation reveals an epigenetic signature in prostate carcinogenesis. PLoS One 2009, 4:e4687.

67. Bernet A, Mazelin L, Coissieux MM, Gadot N, Ackerman SL, Scoazec JY, Mehlen P: Inactivation of the UNC5C Netrin-1 receptor is associated with tumor progression in colorectal malignancies. Gastroenterology 2007, 133:1840-1848.

68. MacLean JA, Rao MK, Doyle KM, Richards JS, Wilkinson MF: Regulation of the Rhox 5 homeobox gene in primary granulosa cells: preovulatory expression and dependence on SP1/SP3 and GABP. Biol Reprod 2005, 73:1126-1134.

69. Gazin C, Wajapeyee N, Gobeil S, Virbasius CM, Green MR: An elaborate pathway required for Ras-mediated epigenetic silencing. Nature 2007, 449:1073-1077.

70. Cheng $X$ : Silent assassin: oncogenic ras directs epigenetic inactivation of target genes. Sci Signal 2008, 1:pe14.

71. Helbig G, Christopherson KW, Bhat-Nakshatri P, Kumar S, Kishimoto H, Miller KD, Broxmeyer HE, Nakshatri H: NF-kappaB promotes breast cancer cell migration and metastasis by inducing the expression of the chemokine receptor CXCR4. J Biol Chem 2003, 278:21631-21638.

72. Donnenberg VS, Meyer EM, Donnenberg AD: Measurement of multiple drug resistance transporter activity in putative cancer stem/progenitor cells. Methods Mol Biol 2009, 568:261-279.

doi:10.1186/1476-4598-10-63

Cite this article as: Li et al:: Homeobox gene Rhox5 is regulated by epigenetic mechanisms in cancer and stem cells and promotes cancer growth. Molecular Cancer 2011 10:63.

\section{Submit your next manuscript to BioMed Central and take full advantage of:}

- Convenient online submission

- Thorough peer review

- No space constraints or color figure charges

- Immediate publication on acceptance

- Inclusion in PubMed, CAS, Scopus and Google Scholar

- Research which is freely available for redistribution

Submit your manuscript at www.biomedcentral.com/submit
Biomed Central 